\title{
KARAKTERISTIK MINERALOGI MATERIAL BIOKERAMIK JENIS KALSIUM FOSFAT DARI CANGKANG KERANG SIMPING
}

(Amusium pleuronectes) Mineralogy Characteristics of Calcium Phosphate Bioceramics from Asian Moon Scallop (Amusium pleuronectes) EggShell Abdul Rachman, Naili Sofiyaningsih,Kristanto Wahyudi Balai Besar Keramik Jl. Jend. Ahmad Yani 392 Bandung, Indonesia pleuronectes) di kab. Brebes telah dimanfaatkan sebagai bahan baku kerajinan hiasan dinding. Untuk memberi nilai tambah yang lebih tinggi, cangkang kerang simping bisa digunakan sebagai prekursor kapur untuk membentuk material biokeramik jenis kalsium fosfat dengan metode presipitasi. Proses sintesis dilakukan dengan metode presipitasi basah dengan pengaturan $\mathrm{pH}$ 6-7, 7-8 dan 8-9 serta kalsinasi pada suhu $800^{\circ} \mathrm{C}-900^{\circ} \mathrm{C}$. Hasil mineralogi dengan menggunakan XRD menunjukkan bahwa suhu kalsinasi tidak memberikan perbedaan bentuk kristal yang signifikan, baik pada suhu $800^{\circ} \mathrm{C}$ maupun $900^{\circ} \mathrm{C}$, namun pengaturan $\mathrm{pH}$ sangat berpengaruh terhadap pembentukan fasa mineral. Fasa mineral $\beta$-trikalsiumfosfat cenderung terbentuk pada $\mathrm{pH}$ 6-7 dan $\mathrm{pH}$ 7-8 sedangkan mineral hidroksiapatit (HAp) akan terbentuk pada pengaturan $\mathrm{pH}$ 8-9. Hasil analisis gugus fungsi (FTIR) pada pH7-8 menunjukkan bahwa pita serapan vibrasi gugus $\mathrm{OH}$ pada panjang gelombang 3650-3000 $\mathrm{cm}^{-1}$ tidak terjadi sehingga fasa mineral yang terbentuk merupakan $\beta$-trikalsiumfosfat sedangkan pada $\mathrm{pH}$ 8-9 dan suhu kalsinasi $900^{\circ} \mathrm{C}$ menunjukkan adanya spektrum dengan pita serapan yang khas pada bilangan gelombang 555,50 dan $609,51 \mathrm{~cm}^{-1}$ serta vibrasi gugus $\mathrm{OH}$ pada panjang gelombang $3650-3000 \mathrm{~cm}^{-1}$ yang menandakan terjadinya pembentukan fasa mineral hidroksiapatit (HAp).

Kata kunci :biokeramik, kerang simping, presipitasi basah, hidroksiapatit, $\beta$-trikalsiumfosfat

\section{ABSTRACT}

sian Moon Scallop (Amusium pleuronectes) shell from Brebes have been utilized for wall decoration. To increase its added value, scallop shell can be used as a calcium precursor formed calcium phosphate 
bioceramics material via wet precipitation method. The bioceramics material synthesis was carried out in variation $\mathrm{pH}$ 6 to 7,7 to 8,8 to 9 and calcination temperature at $800^{\circ} \mathrm{C}$ $900^{\circ} \mathrm{C}$. The mineralogy and functional groups characteristic were investigated using $X$-ray diffraction (XRD) and Fourier Transform infrared spectroscopy (FTIR). The analysis showed that the calcination temperature didn't give a significant differences in crystal form but affected in mineral phase formation. $\beta$-tricalciumphosphate formed at $\mathrm{pH} 6$ to 7 and $\mathrm{pH} 7$ to 8 while hidroxyapatite formed at $\mathrm{pH} 8$ to 9. FTIR analysis showed that vibration band absorption of $\mathrm{OH}$ groups at 3650$3000 \mathrm{~cm}^{-1}$ didn't appear at $\mathrm{pH} 7$ to 8 , the formed mineral phase is $\beta$-tricalciumphosphate. Whereas at $\mathrm{pH} 8-9$ and the calcination temperature of $900^{\circ} \mathrm{C}$ showed the presence of a spectrum with a specific absorption band at wave numbers 555.50 and $609.51 \mathrm{~cm}-1$ and vibrations of $\mathrm{OH}$ groups at wavelengths of 3650-3000 cm-1 which indicates the occurrence of hydroxyapatite (HAp).

Keywords: bioceramic, Amusium pleuronectes, wet precipitation, hydroxiapatite, $\beta$-tricalciumphosphate

\section{PENDAHULUAN}

Sumber daya laut yang diekspor Indonesia selain ikan adalah kerang, terutama jenis kerang simping (Amusium pleuronectes). Daerah penghasil terbesar kerang simping adalah wilayah pantai utara Jawa utamanya Kabupaten Brebes dengan rata-rata 52,82 ton per tahun[1]. Pemanfaatan kerang simping dengan massa per satuan berkisar $250 \mathrm{gr}$ $670 \mathrm{gr}$ adalah daging atau otot aduktornya saja sedangkan cangkangnya massa 53\% - 65\% [2] dengan kandungan kapur $(\mathrm{CaO})$ lebih dari 50\%[3] akan dibuang dan menjadi limbah padat. Tercatat jumlah limbah cangkang kerang simping telah mencapai 2.752 ton dan akan terus bertambah setiap tahunnya[4]. Jumlah limbah padat yang sangat besar ini akan menimbulkan efek negatif bagi manusia dan lingkungannya. Oleh karena itu, perlu dilakukan suatu upaya untuk menanganinya diantaranya adalah sebagai bahan baku kerajinan hiasan dinding atau disain interior, campuran pakan ternak, cookies kaya kalsium[4], tepung kalsium[5] dan biskuit[6].

Upaya lain yang bisa dilakukan untuk menambah nilai dari limbah cangkang kerang adalah memanfaatkannya sebagai material 
biokeramik jenis kalsium fosfat. Material biokeramik jenis kalsium fosfat secara mineralogi bisa berbentuk hidroksiapatit (HAp)[7], $\beta$-tricalcium phosphate $(\beta-\mathrm{TCP})[7,8]$, dan biphasic calcium phosphate (BCP) [9]. Material biokeramik terbentuk dari prekursor kapur dan asam fosfat. Tulang hewan mamalia telah dimanfaatkan sebagai prekursor kapur untuk membentuk material biokeramik. Prekursor kapur lainnya bisa didapatkan dari cangkang kepiting darah dan siput laut [7], cangkang telur $[10,11,14,16,26,27]$, cangkang keong[12], cangkang kerang hijau[13], cangkang tutut[15], cangkang tiram[17][19], kerang kowok (tiger cowrie)[18], cangkang kepiting[20], limbah kerang[21], cangkang kerang darah[22], cangkang keong remis[23], dan cangkang tiram mutiara[24].

Metode sintesis yang telah dikembangkan adalah metode hidrotermal [15,21], mekanokimia[10,11,14] dan presipitasi basah[7,9,12,13,15-20,22,25]. Metode presipitasi basah pertama kali diinisiasi oleh Rathje[9][12][13] dan memiliki kelebihan dibanding metode lainnya antara lain proses sederhana, hasil yang besar (87\%) [9], cocok untuk produksi skala industri, bahan baku murah dan menghasilkan produk $\mathrm{Ca} / \mathrm{P}$ dalam berbagai komposisi fasa [8][9]. Oleh karena itu, penelitian ini menggunakan metode presipitasi basah untuk membuat material biokeramik dari cangkang kerang simping sebagai prekursor kapur. Pengaturan $\mathrm{pH}$ dilakukan pada saat titrasi karena menurut H. R. Le [28] pada $\mathrm{pH} 7$ material yang terbentuk adalah calcium hidrophosphate(CHP) dan pada $\mathrm{pH} 9$ material yang terbentuk adalah HAp [17]. Hasil sintesis akan dikalsinasi pada suhu $800^{\circ} \mathrm{C}$ dan $900^{\circ} \mathrm{C}$, dimana suhu kalsinasi cukup berpengaruh terhadap pembentukan material biokeramik. HAp mulai terbentuk pada suhu $900^{\circ} \mathrm{C}$ $[10,11,17,21]$.

Karakterisasi hasil penelitian dilakukan dengan Xray-Diffraction [922] untuk mengetahui jenis kristal yang terbentuk dan Fourier Transform Infrared Spectroscopy (FTIR) untuk mengetahui absorbsi gugus fungsi dalam pembentukan mineral diantaranya ikatan $\mathrm{PO}_{4}^{3-}$, gugus $\mathrm{OH}$ dan gugus karbonat $\mathrm{CO}_{3}{ }^{2-}[17,22]$. 


\section{METODOLOGI PENELITIAN}

Diagram alir pembuatan material biokeramik jenis kalsium fosfat dari cangkang kerang simping ditunjukkan pada Gambar 1.

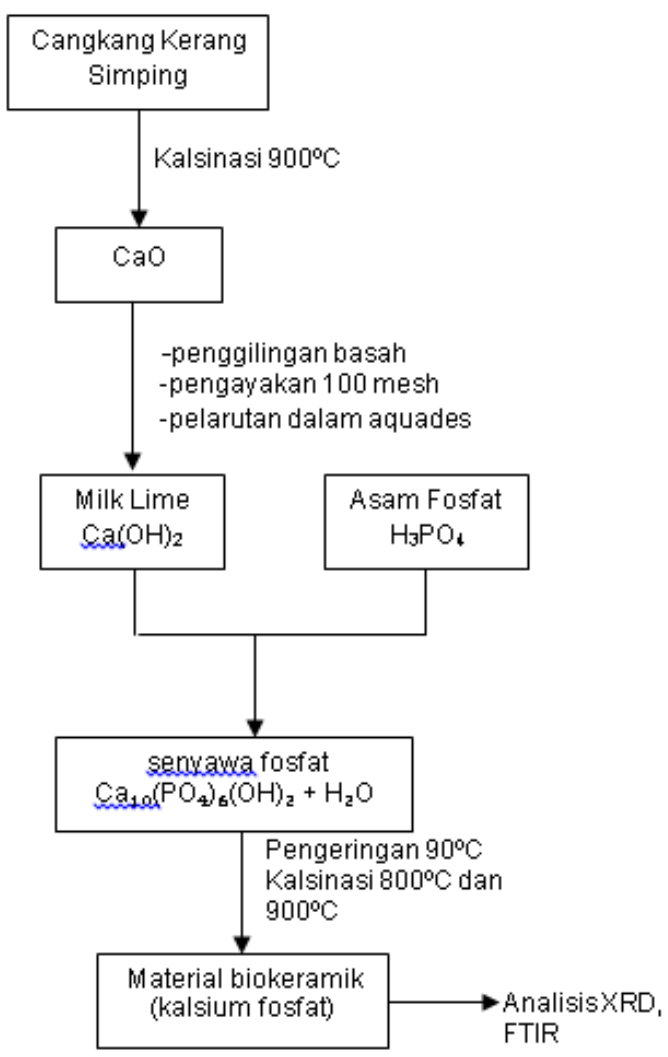

Gambar 1. Diagram Alir pembuatan material biokeramik jenis kalsium fosfat dari cangkang kerang simping

Material biokeramik dari cangkang kerang simping disintesis dengan bahan baku utama adalah limbah cangkang kerang simping dari Kabupaten Brebes Jawa Tengah sebagai prekursor kapur dan asam fosfat teknis food grade dari Sun Plan Development Ltd, konsentrasi 85\% No batch DL 201702065A. Sintetis dilakukan dengan metode presipitasi basah sedangkan variabel yang digunakan adalah $\mathrm{pH}$ pembentukan dan suhu kalsinasi seperti tercantum pada Tabel 1.

Tabel 1. Kode sampel penelitian

\begin{tabular}{ccc}
\hline $\begin{array}{c}\text { Kode } \\
\text { Sampel }\end{array}$ & $\begin{array}{c}\text { pH } \\
\text { pembentukan }\end{array}$ & $\begin{array}{c}\text { Suhu } \\
\text { Kalsinasi }\end{array}$ \\
\hline I & $6-7$ & 800 \\
II & $6-7$ & 900 \\
III & $7-8$ & 800 \\
IV & $7-8$ & 900 \\
V & $8-9$ & 800 \\
VI & $8-9$ & 900 \\
\hline
\end{tabular}

Tahap pertama yang dilakukan adalah kalsinasi cangkang kerang simping pada suhu $900^{\circ} \mathrm{C}$ untuk menghasilkan prekursor kapur berupa $\mathrm{CaO}$ amorf $[12,13,16]$. Hasil kalsinasi selanjutnya digiling basah dalam potmill porselen dan disaring dengan ayakan \pm 100 mesh. Selanjutnya dilarutkan dalam aquades sampai membentuk $\mathrm{Ca}(\mathrm{OH})_{2}$ (milk lime) dan diaduk dengan kecepatan 700 rpm. Larutan $\mathrm{Ca}(\mathrm{OH})_{2}$ dititrasi dengan asam fosfat sedikit demi sedikit dengan metode

presipitasi basah[9][12][13]menurut persamaan reaksi sebagai berikut :

$$
\begin{aligned}
& 10 \mathrm{Ca}(\mathrm{OH})_{2}+6 \mathrm{H}_{2} \mathrm{PO}_{4} \rightarrow \\
& \mathrm{CO}_{10}\left(\mathrm{PO}_{4}\right)_{6}(\mathrm{OH})_{2}+18 \mathrm{H}_{2} \mathrm{O}[9]
\end{aligned}
$$


Kontrol pH dilakukan pada $\mathrm{pH}$ 6-7, 7-8 dan 8-9. Hasil reaksi selanjutnya dikeringkan dalam oven pada suhu $90^{\circ} \mathrm{C}$ dan dikalsinasi pada suhu $800^{\circ} \mathrm{C}$ dan $900^{\circ} \mathrm{C}$. Hasil kalsinasi yang terbentuk selanjutnya dianalisis dengan XRD PANalytical - X'Pert HighScore radiasi Cu-Ka $(\lambda=0.154 \mathrm{~nm})$ dan FT-IRBuck M500 Scientific untuk mengidentifikasi gugus fungsi terutama gugus $\mathrm{OH}$ yang spesifik untuk hidroksiapatit (HAp).

\section{III.HASIL DAN PEMBAHASAN}

Hasil analisis kimia terhadap cangkang kerang simping menunjukkan bahwa komposisi utama adalah $\mathrm{CaO}$ dengan kadar 52,34 \%. Berdasarkan perhitungan stokiometri, maka $1 \mathrm{~kg}$ cangkang kerang simping dapat menghasilkan sekitar 467 gram HAp.

\subsection{Karakteristik Mineralogi}

Karakterisasi mineralogi dilakukan terhadap 6 (enam) sampel sesuai dengan kode pada Tabel 1. Gambar 2 menunjukkan karakteristik mineral sampel yang disintesis dari $\mathrm{Ca}(\mathrm{OH})_{2}$ dan $\mathrm{H}_{3} \mathrm{PO}_{4}$ pada perbandingan mol 1:1, $\mathrm{pH}$ pembentukan 6-7 dan suhu kalsinasi $800^{\circ} \mathrm{C}$. Reaksi yang terjadi cenderung bersifat asam dan terbentuk bebasan $\mathrm{H}_{3} \mathrm{PO}_{4}$ sesuai mekanisme reaksi sebagai berikut :

$$
\begin{aligned}
& 3\left(\mathrm{Ca}(\mathrm{OH})_{2}+\mathrm{H}_{3} \mathrm{PO}_{4}\right) \rightarrow \\
& \beta \mathrm{Ca}_{3}\left(\mathrm{PO}_{4}\right)_{2}+\mathrm{H}_{3} \mathrm{PO}_{4}+6 \mathrm{H}_{2} \mathrm{O} .
\end{aligned}
$$

Dengan kondisi reaksi demikian, fasa mineral yang terbentuk mengarah kepada $\beta$-TCP dan praktis tidak terbentuk mineral fosfat lainnya. Hal ini diperkuat dengan adanya puncakpuncak utama pada sudut difraksi $2 \theta$ $30,96^{\circ} ; 34,27^{\circ} ; 27,73^{\circ}$; dan $52,87^{\circ}$ yang memperlihatkan terbentuknya mineral $\beta$-TCP ( $\beta$-trikalsium fosfat).

Gambar 3 menunjukkan sampel yang dikalsinasi pada suhu $900^{\circ} \mathrm{C}$ memperlihatkan pola difraktogram yang sama dengan sampel yang dikalsinasi pada suhu $800^{\circ} \mathrm{C}$. Namun demikian, intensitas puncak-puncak utamanya meningkat seiring dengan kenaikan suhu kalsinasi. Hal ini menunjukkan adanya peningkatan derajat kristalinitas mineral kalsium fosfat yang dihasilkan. 


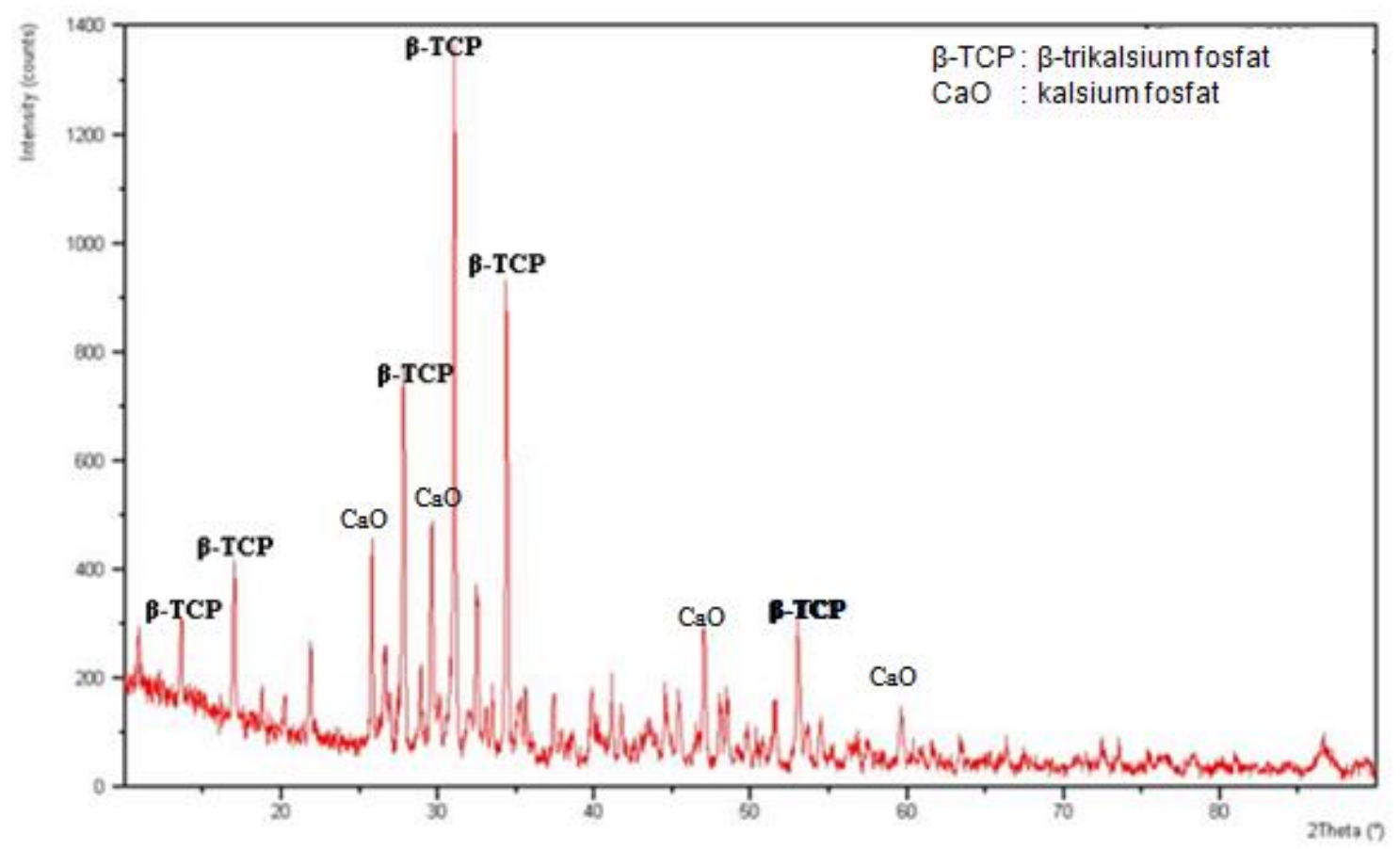

Gambar 2. Difraktogram sampel pH pembentukan 6-7 dan suhu kalsinasi $800^{\circ} \mathrm{C}$

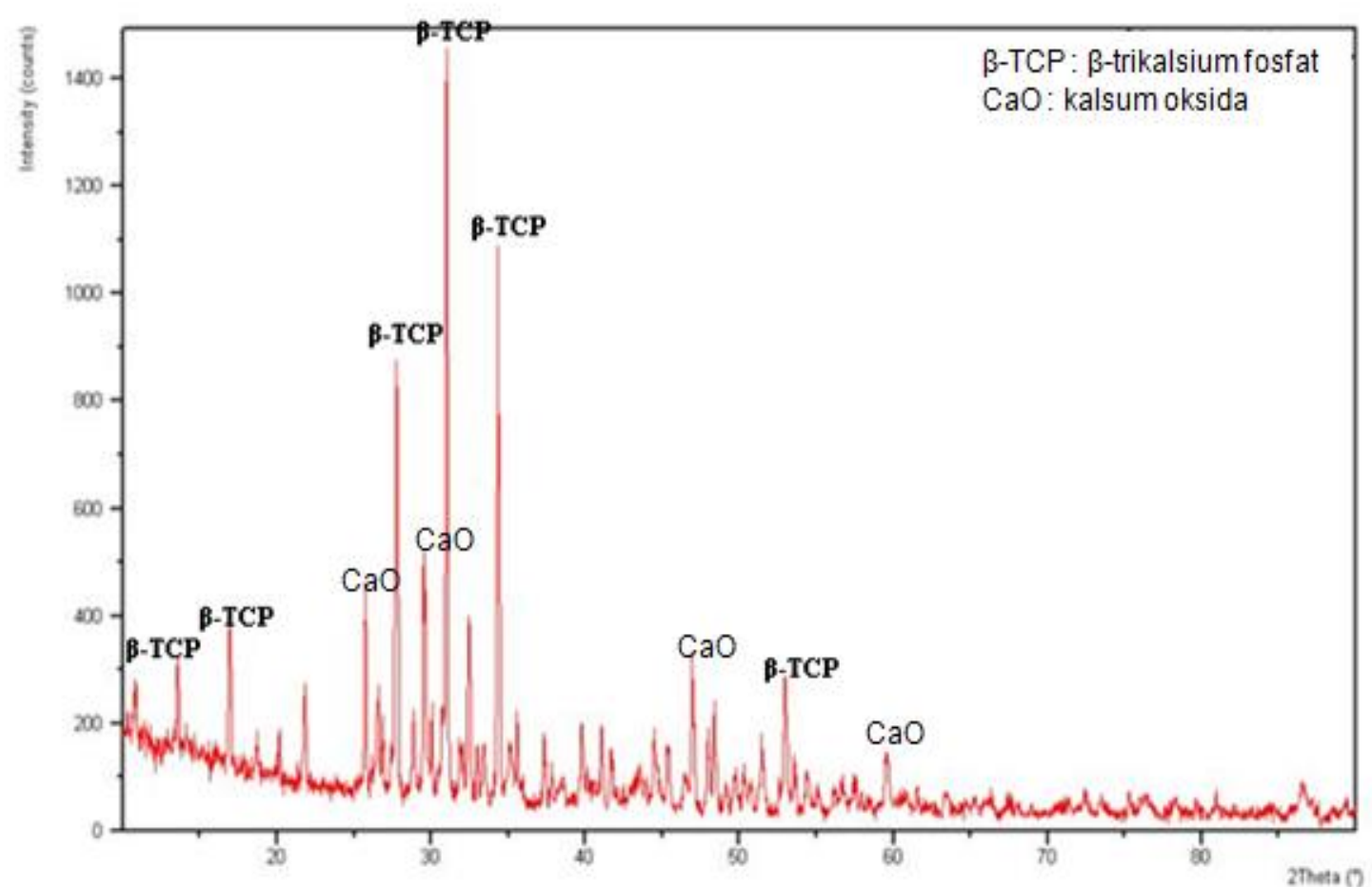

Gambar 3. Difraktogram sampel pH pembentukan 6-7 dan suhu kalsinasi $900^{\circ} \mathrm{C}$

Gambar 4 dan Gambar 5 dilakukan terhadap sampel yang merupakan hasil analisis XRD yang diperoleh dari reaksi $\mathrm{Ca}(\mathrm{OH})_{2}$ dan 
$\mathrm{H}_{3} \mathrm{PO}_{4}$ dengan perbandingan mol 2:1. utama $\beta$-TCP, sesuai dengan $\mathrm{pH}$ pembentukan dalam reaksi mekanisme reaksi :

tersebut ditetapkan 7-8, suhu kalsinasi $800^{\circ} \mathrm{C}$ dan $900^{\circ} \mathrm{C}$. Hasil menunjukkan bahwa material biokeramik yang dihasilkan adalah murni kristal ( $\beta$ TCP) sesuai dengan database PDF 2. No. 090169. Hal ini ditandai dengan adanya puncak-puncak utama $\beta$ trikalsium fosfat ( $\beta$-TCP) yang ditunjukkan pada sudut difraksi $2 \theta$ yaitu $27,73^{\circ} ; 30,96^{\circ} ; 34,27^{\circ} 52,87^{\circ}$. Secara teoritis perbandingan $\mathrm{mol}$ $\mathrm{Ca}(\mathrm{OH})_{2}$ terhadap $\mathrm{H}_{3} \mathrm{PO}_{4}$, tepatnya $(1,5: 1)$ dapat menghasilkan mineral

$$
\begin{aligned}
& 3 \mathrm{Ca}(\mathrm{OH})_{2}+2 \mathrm{H}_{3} \mathrm{PO}_{4} \rightarrow \\
& \beta \mathrm{Ca}_{3}(\mathrm{PO} 4)_{2}+6 \mathrm{H}_{2} \mathrm{O} .
\end{aligned}
$$

Dengan kondisi pembentukan $\mathrm{pH}$ 7-8 atau bersifat basa, masih terdapat fasa mineral kapur $(\mathrm{CaO})$ bebas. Reaksi yang terjadi adalah sebagai berikut :

$$
\begin{aligned}
& 4 \mathrm{Ca}(\mathrm{OH})_{2}+2 \mathrm{H}_{3} \mathrm{PO}_{4} \quad \text { pH: }: 7-8 \quad \longrightarrow \\
& \beta \mathrm{Ca}_{3}\left(\mathrm{PO}_{4}\right)_{2}+\mathrm{CaO}+7 \mathrm{H}_{2} \mathrm{O} .
\end{aligned}
$$

Puncak-puncak utama pada sudut difraksi $2 \theta \quad 32,21^{\circ}, \quad 37,32^{\circ} ;$ dan 53,93ํmerupakan puncak khas dari fasa mineral kapur .

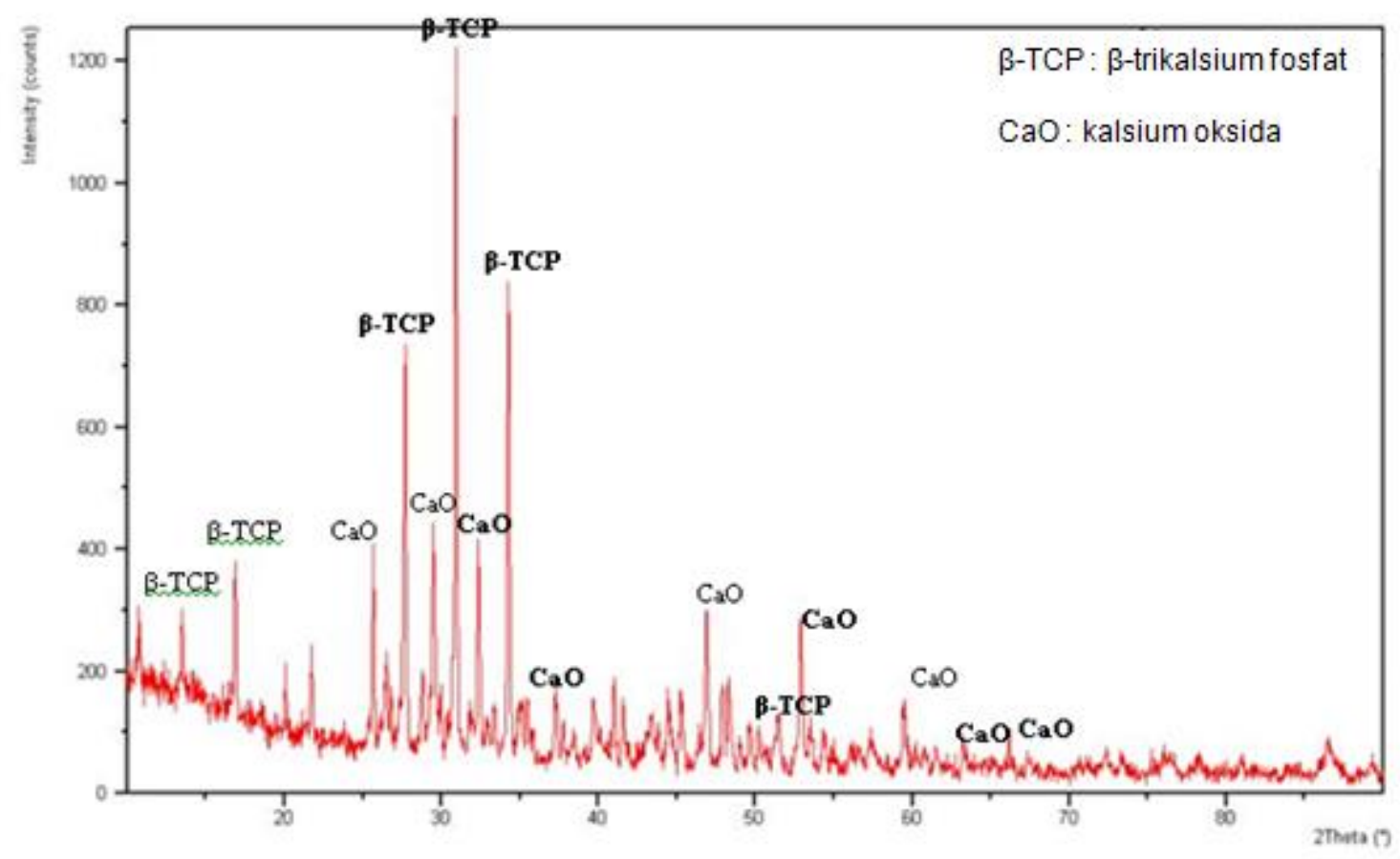

Gambar 4. Difraktogram sampel $\mathrm{pH}$ pembentukan $7-8$ dan suhu kalsinasi $800^{\circ} \mathrm{C}$ 


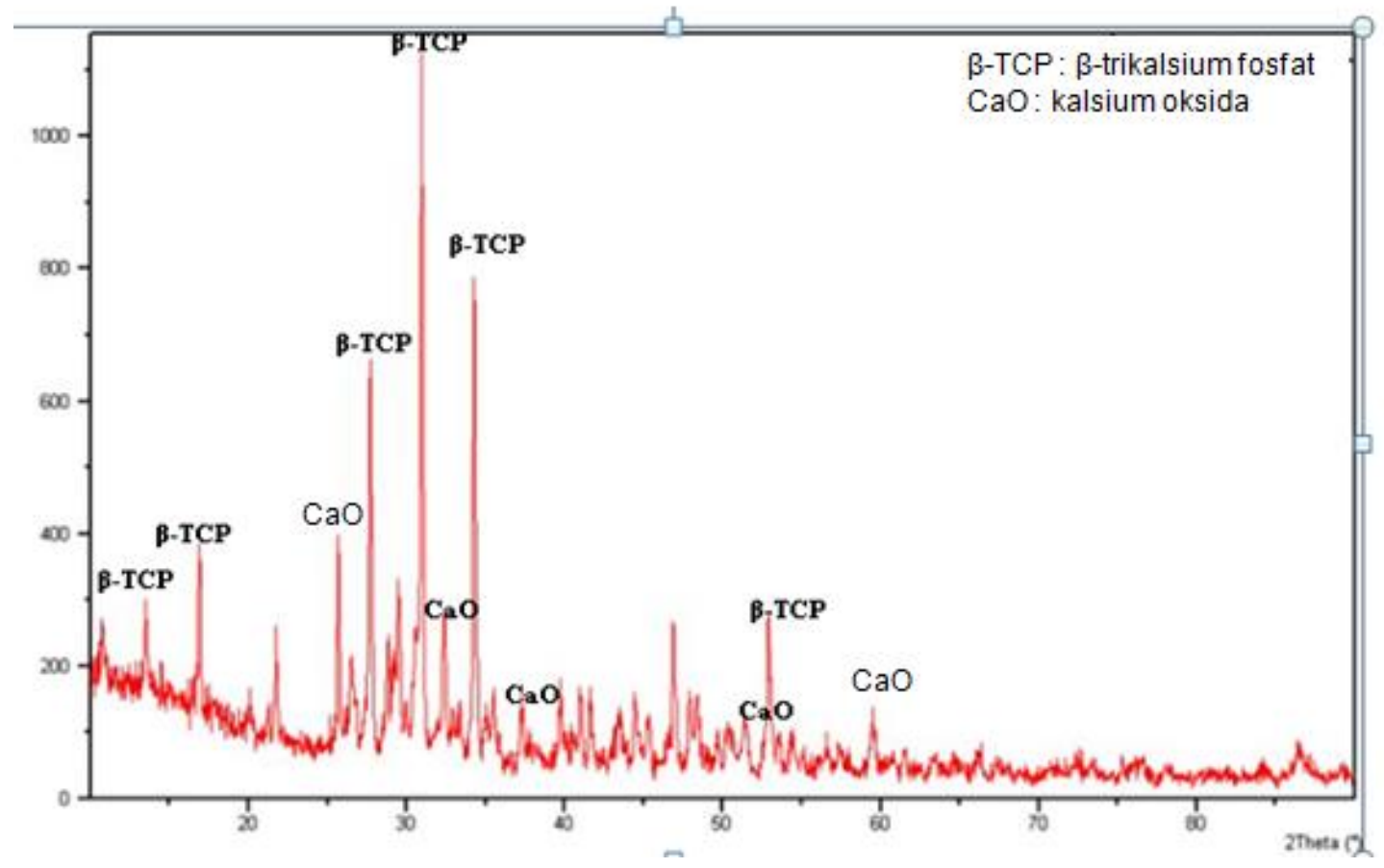

Gambar 5. Difraktogram sampel pH pembentukan 7-8 dan suhu kalsinasi $900^{\circ} \mathrm{C}$

Gambar 6 menunjukkan hasil analisis XRD dari sampel yang disintesis melaluireaksi $\mathrm{Ca}(\mathrm{OH})_{2}$ dan $\mathrm{H}_{3} \mathrm{PO}_{4}$ pada perbandingan mol 6:1, $\mathrm{pH}$ pembentukan 8-9 dan suhu kalsinasi $800^{\circ} \mathrm{C}$. Pola difraktogram tersebut menunjukkan terbentuknya fasa mineral HAp sesuai dengan database XRX, PDF 2. 841998 dan fasa mineral kalsium oksida $(\mathrm{CaO})$ sesuai dengan database, PDF 2.821690 sebagai fasa mineral yang dominan. Keberadaan mineral HAp ditandai dengan adanya puncakpuncak utama pada sudut difraksi $2 \theta$

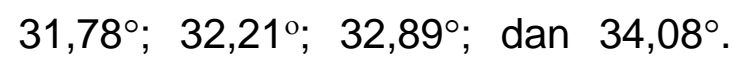
Selain itu, adanya puncak utama pada sudut difraksi $2 \theta \quad 32,21^{\circ} ; 37,32^{\circ}$; 53,93; 64,26 ${ }^{\circ}$ dan $67,49^{\circ}$ merupakan puncak-puncak khas dari fasa mineral $\mathrm{CaO}$ yang terbentuk sebagai kelebihan dari $\mathrm{Ca}(\mathrm{OH})_{2}$ dalam awal proses sintesis. Dengan peningkatan suhu kalsinasi menjadi $900^{\circ} \mathrm{C}$, maka derajat kristalinitas mineral HAp juga semakin meningkat. Hal ini ditandai dengan intensitas puncak-puncak utama mineral hidroksiapaptit (HAp) dalam pola difraktogram menjadi lebih tinggi seperti terlihat pada Gambar 6. Kondisi $\mathrm{pH}$ pembentukan sebesar 8-9 merupakan kondisi yang terlalu basa untuk pembentukan HAp sehingga fasa mineral cenderung didominasi 
oleh bebasan kapur $(\mathrm{CaO})$ seperti yang terlihat pada reaksi berikut :

$3\left(6 \mathrm{Ca}(\mathrm{OH})_{2}+\mathrm{H}_{3} \mathrm{PO}_{4}\right) \rightarrow$

$13 \mathrm{CaO}+\mathrm{Ca}_{5}\left(\mathrm{PO}_{4}\right)_{3} \mathrm{OH}+22 \mathrm{H}_{2} \mathrm{O}$.

Walaupun secara umum kondisi pembentukan HAp ini ditetapkan pada $\mathrm{pH}=8-9$, yang perlu disubstitusi oleh 1 mol $\mathrm{H}_{3} \mathrm{PO}_{4}$ lagi menjadi $\mathrm{pH}=7-8$, sehingga HAp yang terbentuk termasuk tipe $\left.\mathrm{Ca}_{5}\left(\mathrm{PO}_{4}\right)_{3} \mathrm{HPO}_{4}\right)$ atau $\left(\mathrm{Ca}_{10}\left(\mathrm{PO}_{4}\right) 6 \mathrm{HPO}_{4}\right)$. Fasa mineral yang terbentuk pada berbagai variasi $\mathrm{pH}$ pembentukan dan suhu kalsinasi ditunjukkan pada Tabel 2.

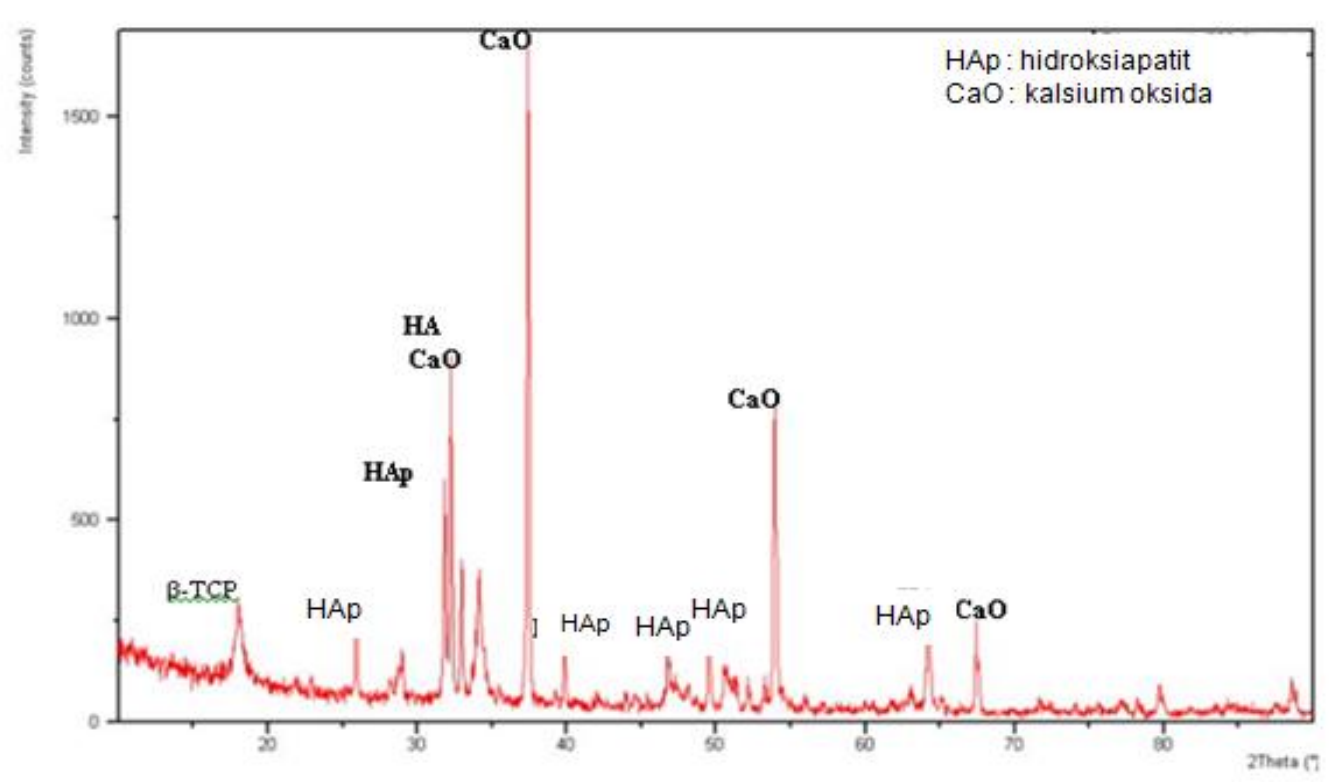

Gambar 6. Difraktogram sampel pH pembentukan 8-9 dan suhu kalsinasi $800^{\circ} \mathrm{C}$

Tabel 2. Fasa Mineral berdasarkan $\mathrm{pH}$ pembentukan dan suhu pembakaran

\begin{tabular}{|c|c|c|c|}
\hline $\begin{array}{l}\text { Kode } \\
\text { Sampel }\end{array}$ & $\begin{array}{c}\mathrm{pH} \\
\text { pembentukan }\end{array}$ & $\begin{array}{l}\text { Suhu } \\
\text { Kalsinasi }\end{array}$ & $\begin{array}{l}\text { Jenis } \\
\text { Mineral }\end{array}$ \\
\hline 1 & $6-7$ & 800 & $\begin{array}{c}\beta \text {-trikalsiumfosfat } \\
\text { kalsium oksida }\end{array}$ \\
\hline II & $6-7$ & 900 & $\begin{array}{l}\beta \text {-trikalsiumfosfat } \\
\text { kalsium oksida }\end{array}$ \\
\hline III & $7-8$ & 800 & $\begin{array}{l}\beta \text {-trikalsiumfosfat } \\
\text { kalsium oksida }\end{array}$ \\
\hline IV & $7-8$ & 900 & $\begin{array}{c}\beta \text {-trikalsiumfosfat } \\
\text { kalsium Oksida }\end{array}$ \\
\hline V & $8-9$ & 800 & $\begin{array}{c}\text { HAp } \\
\text { kalsium oksida }\end{array}$ \\
\hline VI & $8-9$ & 900 & $\begin{array}{c}\text { HAp } \\
\text { kalsium oksida }\end{array}$ \\
\hline
\end{tabular}




\subsection{Karakteristik FTIR}

Untuk mengidentifikasi gugus fungsi fasa mineral yang terbentuk dan memperkuat hasil analisis XRD maka dilakukan uji FTIR. Uji FTIR dilakukan pada sampel IV dan sampel VI yang masin-masing mewakili senyawa $\beta$-trikalsiumfosfat dan HAp. Hasil analisis FTIR sampel IV, $\mathrm{pH}$ pembentukan 7-8 dan suhu kalsinasi 900ㄷ ditunjukkan pada Gambar 7. Hasil analisis tersebut memperlihatkan spektrum dengan pita serapan pada bilangan gelombang 300-4000 $\mathrm{cm}^{-1}$. Pita serapan pada bilangan gelombang 462,92 $\mathrm{cm}^{-1}$ menunjukkan mode vibrasi lenturan v2 dari ikatan O-P-O. Sedangkan pita serapan kembar pada bilangan gelombang
555,50 dan 609,51 $\mathrm{cm}^{-1}$ merupakan dua pita serapan khas HAp untuk mode vibrasi lenturan $v_{4}$ dari ikatan $\mathrm{O}$ P-O yang menunjukkan terjadinya kristal HAp[21]. Pita serapan pada bilangan gelombang 941,26 $\mathrm{cm}^{-1}$ merupakan mode vibrasi regangan simetris $v_{1}$ dari ikatan P-O. Pita serapan yang lebar pada bilangan gelombang 1041,56 cm-1 merupakan mode vibrasi v3 dari ikatan O-P. Pita serapan pada bilangan gelombang 1445,44 $\mathrm{cm}^{-1}$ merupakan adanya mode vibrasi dari ikatan $\mathrm{CO}^{2-}$. Mode vibrasi lenturan dari gugus $-\mathrm{OH}$ dari molekul $\mathrm{H} 2 \mathrm{O}$ tidak muncul pada pita serapan bilangan gelombang 3650$3000 \mathrm{~cm}^{-1}$ yang menunjukkan bahwa material masih dalam bentuk $\beta$-TCP.

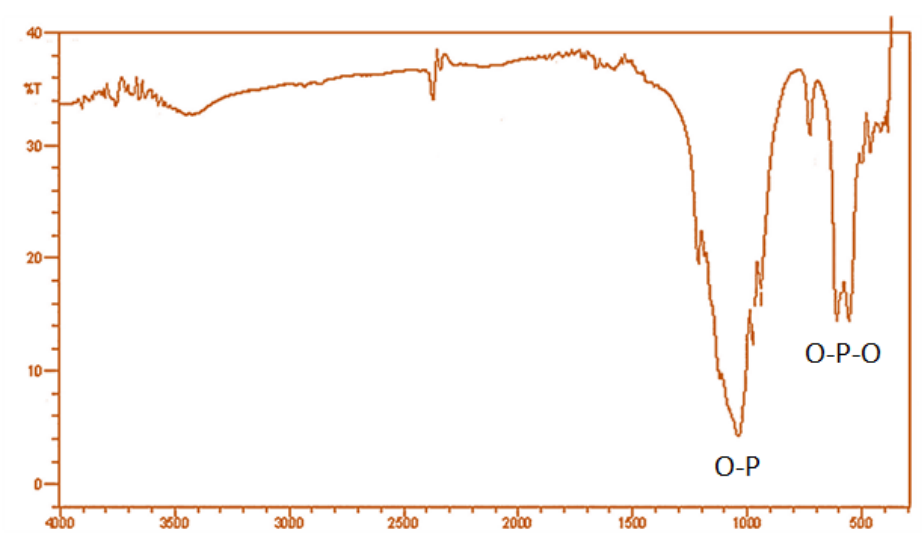

Gambar 7. Hasil analisis FT-IR terhadap sampel $\mathrm{pH}=7-8$, suhu kalsinasi $900{ }^{\circ} \mathrm{C}$

Hasil analisis FTIR terhadap sampel pembentukan pada $\mathrm{pH}=8-9$, suhu kalsinasi $900^{\circ} \mathrm{C}$ ditunjukkan pada Gambar 8, menunjukkan spektrum $\mathrm{CaO}$ yang khas dengan pita serapan pada bilangan gelombang 408,91; 887,26; 1435,04; dan 3641,60 $\mathrm{cm}^{-1}[40,41,42]$. Pita serapan dengan 
intensitas tajam dan kuat pada bilangan gelombang 408,91 $\mathrm{cm}^{-1}$ kemungkinan dihasilkan dari vibrasi regangan ikatan logam oksigen $\mathrm{Ca}-\mathrm{O}$. Pita serapan pada bilangan gelombang $887,26 \mathrm{~cm}^{-1}$ merupakan mode vibrasi khas dari $\mathrm{CaO}$ [42]. Sedangkan pita serapan pada bilangan gelombang $3641,60 \mathrm{~cm}^{-1}$ terdeteksi dari sisa basa -OH yang terikat pada atom Ca $[40,41]$. Adapun bilangan gelombang sekitar 455,17 $\mathrm{cm}^{-1}$ dan 486,21 $\mathrm{cm}^{-1}$ merupakan mode lenturan v2 dari ikatan O-P-O dari mineral HAp. Sedangkan pita serapan pada bilangan gelombang sekitar 524,64, 570,93 dan $600 \mathrm{~cm}^{-}$ ${ }^{1}$ teridentifikasi sebagai mode vibrasi lenturan v4 dari ikatan O-P-O pada mineral HAp. Pita serapan pada bilangan gelombang 964,41 $\mathrm{cm}^{-1}$ menunjukkan mode vibrasi regangan simetris $v_{1}$ dari ikatan P-O pada mineral HAp. Pita serapan yang lebar pada bilangan gelombang 1041,58 dan 1095,57 $\mathrm{cm}^{-1}$ merupakan mode vibrasi vз dari ikatan O-P pada mineral HAp [29,30,35]. Mode vibrasi lenturan dari gugus $-\mathrm{OH}$ dari molekul $\mathrm{H}_{2} \mathrm{O}$ muncul pada pita serapan bilangan gelombang $3650-3000 \mathrm{~cm}^{-1}$ yang menunjukkan bahwa material tersebut adalah HAp. Perbandingan antara bilangan gelombang serapan antara teoritis dan hasil sintesis pada masing-masing senyawa $\beta$-trikalsium fosfat dan HAp ditunjukkan pada Tabel 3.

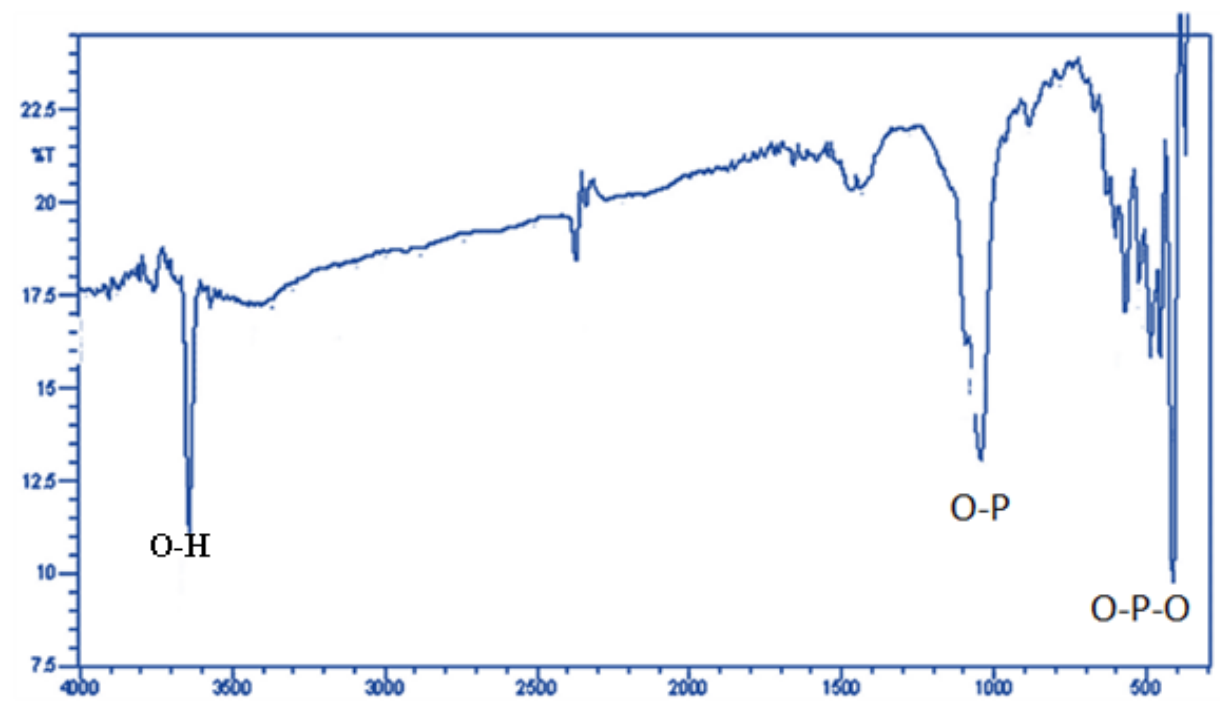

Gambar 8. Hasil analisis FT-IR terhadap sampel pH 8-9 suhu kalsinasi $900{ }^{\circ} \mathrm{C}$ 
Tabel 3. Perbandingan panjang gelombang pita serapan $\beta$-TCP dan HAp hasil sintesis dan teoritis

\begin{tabular}{ccccc}
\hline \multirow{2}{*}{ Gugus } & \multicolumn{3}{c}{ Panjang Gelombang $\left(\mathbf{c m}^{-1}\right)$} \\
& & $\begin{array}{c}\text { Hasil Sintesis } \\
(\boldsymbol{\beta}-\mathrm{TCP})\end{array}$ & $\begin{array}{c}\text { Hasil Sintesis } \\
\text { (HAp) }\end{array}$ & Teoritis HAp[22] \\
\hline & V1 & 941,26 & 964,41 & $970-962$ \\
& V2 & 462,92 & 486,21 & $472-466$ \\
$\mathrm{PO}_{4}{ }^{3-}$ & V3 & 1041,56 & 1041,$58 ; 1095,57$ & $1093-1041$ \\
& V4 & 555,$50 ; 609,51$ & 524,$64 ; 570,93$, & $603 ; 570$ \\
& & - & 600 & $3650-3000$ \\
$\mathrm{OH}^{-}$ & & 1445,44 & 3641,60 & $1440-1456$ \\
$\mathrm{CO}^{2-}$ & & & 1435,04 & \\
\hline
\end{tabular}

\section{KESIMPULAN}

Berdasarkan karakteristik mineralogi dan ikatan gugus fungsi maka dapat diperoleh kesimpulan bahwa pembentukan material biokeramik dari kerang simping (Amusium pleuronectes) dengan metoda presipitasi basah tergantung pada kontrol pH. Pada $\mathrm{pH}$ 6-7 fasa mineral yang terbentuk mengarah pada $\beta$-TCP, pada $\mathrm{pH} 7-8$ cenderung terbentuk $\beta$-TCP, dan pada $\mathrm{pH}$ basa 89 cenderung terbentuk fasa mineral HAp dan $\mathrm{CaO}$ sebagai fasa mineral yang dominan. Kedua fasa mineral tersebut dapat diperoleh pada suhu kalsinasi $800^{\circ} \mathrm{C}-900^{\circ} \mathrm{C}$. Hasil analisis gugus fungsi (FTIR) pada $\mathrm{pH}$ 7-8 menunjukkan bahwa pita serapan vibrasi gugus $\mathrm{OH}$ tidak terjadi sehingga fasa mineral yang terbentuk merupakan $\beta$-trikalsiumfosfat sedangkan pada pH 8-9 dan suhu kalsinasi $900^{\circ} \mathrm{C}$ menunjukkan adanya spektrum dengan pita serapan yang khas pembentukan fasa mineral HAp.

\section{Ucapan Terima Kasih}

Pada kesempatan ini, penulis tidak lupa menyampaikan rasa terima kasih kepada Peneliti Utama Balai Besar Keramik Bapak Suhanda yang telah berkenan menjadi narasumber di dalam penelitian ini.

\section{DAFTAR PUSTAKA}

1. Johan Danu Prasetya, Jusup Suprijanto dan Johannes Hutabarat, "Potensi Kerang Simping (Amusium pleuronectes) Di Kabupaten Brebes Jawa Tengah", Conference paper: Seminar Nasional Tahunan VII Hasil Penelitian Perikanan dan 
Kelautan, Universitas Gadjah Mada, At Jogjakarta Indonesia, 2010.

2. Tri W, Agustini, "Utilization of Asian Moon Scallop (Amusim pleurinectes) Shell for Calcium Resource Formulation (In vivo) and its Application on Fish-based Product". OMICS Publishing Group, 2014.

3. Habibah Abidin , Y.S. Darmanto, Romadhon," Fortifikasi Berbagai Jenis Tepung Cangkang Kerang Pada Proses Pembuatan Roti Tawar", Jurnal Pengolahan Dan Bioteknologi Hasil Perikanan, Vol. 5 No. 2 (2016).

4. Tri Winarni Agustini, A.Suhaeli Fahmi, Ita Widowati, Agus Sarwono, "Pemanfaatan Limbah Cangkang Kerang Simping (Amusium pleuronectes) Dalam Pembuatan Cookies Kaya Kalsium", Jurnal Pengolahan Hasil Perikanan Indonesia, Volume XIV Nomor 81, Hal 8-13,2011

5. Susana E. Ratnawati, Tri W. Agustini, Johannes Hutabarat, "Penilaian Hedonik dan Perilaku Konsumen Terhadap Snack Yang Difortifikasi Tepung Cangkang Kerang Simping (Amusim sp)",
Jurnal Perikanan (J. Fish. Sci.) XV (2): 88-103 ISSN: 0853-6384.

6. R. Marwita Sari Putri, Hermiza Madesci, "Uji Hedonik Biskuit Cangkang Kerang Simping Dari Perairan Indragiri Hilir", Jurnal Teknologi Pertanian, Vol. 7, No. 2 Tahun 2018.

7. Anchana devi.C \& Priya Perumal, "Synthesis \& Application of Hydroxyapatite Bioceramics fromDifferent Marine Sources", Journal of Research in Environmental and Earth Science, Volume 2, Issue 11 pp: 0715(2016)

8. Ola Saleh Mahdi, "Preparation of Hydroxyapatite from Natural Resources", Journal Material Science, Vol 5, Issue 2, October 2018.

9. Kristine Salma, Liga BerzinaCimdina, Natalija Borodajenko, "Calcium phosphate bioceramics prepared from wet chemically precipitated powders", Processing and Application of Ceramics 4 [1] 45-51(2010).

10. Gre'ta Gergely, Ferenc We'ber, Istva'n Luka'cs, Attila L. To'th, Zsolt E. Horva'th, Judit Mihap'ly, Csaba Bala'zsi, Preparation and characterization of hydroxyapatite 
from eggshell, Ceramics International 36, 803-806, (2010)

11. Gre'ta Gergely, et al, "Preparation and characterization of hydroxyapatite from eggshell and seashell", Materials Science Forum, 2010.

12.M.Dasgupta Adak, and K. M. Purohit, "Synthesis of Nanocrystalline Hydroxyapatite from Dead Snail Shellsfor Biological Implantation", Trends Biomater. Artif. Organs, 25(3), 101-106 (2011).

13.S. Santosh and S. Balasivanandha Parbu, "Characterization Of NanoHydroxyapatite Synthesized From Sea Shells Throught Wet Chemical Method", International Journal of Nanoscience, Vol. 11, No. 5 (2012).

14.Sang-Woon Lee, et al, "Comparative Study of Hydroxyapatite Prepared from Seashells and Egg shells as a Bone Graft Material", Tissue Engineering and Regenerative Medicine, Vol. 11, No. 2, pp 113120 (2014).

15. Lenita Herawaty, "Sintesis Nano Hidroksiapatit dari cangkang Tutut (Bellamya javanica) dengan Metode Presipitasi dan Hidrotermal", Tesis, Sekolah
Pascasarjana, Institut Pertanian Bogor, 2014.

16.P. Kamalanathana, et al, "Synthesis and sintering of hydroxyapatite derived from eggshellsas a calcium precursor"r, Ceramics International $40 \quad \mathrm{pp}$ 16349-16359(2014).

17. Sawittree Rujitanapanich, Pitoon Kumpapan, Panthong Wanjanoi, "Synthesis of Hydroxyapatite from Oyster Shell via Precipitation", Energy Procedia 56 pp 112 - 117 (2014).

18.Y. M. "Sahin,et al, "NanoBioceramic Synthesis from Tropical Sea Snail Shells(Tiger Cowrie - Cypraea Tigris) withSimple Chemical Treatment", Acta Physica Polonica, No 4 Vol. 127 (2015)

19.Sota Terasaka, Masanobu Kamitakahara, Taishi Yokoi and Hideaki Matsubara, "Ability of Hydroxyapatite Synthesized from Waste Oyster Shellsto Remove Fluoride lons, "Materials Transactions, Vol. 56, No. 9 pp. 1509 to $1512(2015)$

20. Indah Raya, dkk, "Synthesis and Characterizations of Calcium Hydroxyapatite Derived from Crabs Shells (Portunus pelagicus) and Its Potencyin Safeguard against to 
Dental Demineralizations", International Journal of Biomaterials, 2015

21. Ahmad Fadli, Silvia Reni Yenti, Zultiniar Zultiniar, Rahma Fifiyana, "Hydroxyapatite from Sea Shells Synthesized byLow Temperature Hydrothermal Method", International Conference on Technology, Innovation, and Society (ICTIS 2015)

22. Bulkis Musa, Indah Raya and Hasnah Natsir, "Synthesis and Characterizations of Hydroxyapatite Derived Blood Clam Shells (Anadara granosa) and Its Potency to Dental Remineralizations", International Journal of Applied Chemistry.ISSN 0973-1792 Volume 12, Number 4 pp. 527-538(2016)

23. Florin Miculescu, et al, "Facile synthesis and characterization of hydroxyapatite particles for high value nanocomposites and biomaterials", J. Vacuum, Volume 146, December 2017.

24. Ravi Krishna Brundavanam, Derek Fawcett, Gérrard Eddy Jai Poinern, "Synthesis of a bone like composite material derived from waste pearl oyster shells for potential bone tissue bioengineering applications", International Journal of Research in Medical Sciences, Jun;5(6):2454-2461 (2017)

25.S. E Cahyaningrum, N. Herdyastuty, B. Devina and D. Supangat, "Synthesis and Characterization of Hydroxyapatite Powderby Wet Precipitation Method", International Conference on Chemistry and Material Science (IC2MS) 2017.

26. Sandra Sánchez-Salcedo et al, "Synthesis of bioceramic foams from natural products", J. So-Gel Science and Technology, 2016.

27.S.M. Naga, H.F. El-Maghraby, M.Sayed, E.A. Saad, "Highly Porous Scaffolds Made of Nanosized Hydroxyapatite Powder Synthesized from Eggshells", J. Ceramic Science and Technology, 06[03]237-244 (2015)

28. H. R. Lea, K. Y. Chen, C. A. Wang, "Effect of $\mathrm{pH}$ and Temperature on the Morphology and Phases of CoprecipitatedHydroxyapatite", Journal Of Sol-Gel Science And Technology, 2012.

29. C. Qi, Y-J. Zhu, F. Chen, dan J. Wu, "Porous microspheres of magnesium whitlockite and amorphous calcium magnesium 
phosphate: microwave-assisted rapid synthesis using creatine phosphate, and application in drug delivery", J. Mater. Chem. B, Vol. [3], 7775-7786, (2015).

30. M. Hafezia, M. Abbasi-shahnib, A. Zamaniana dan S. Hesarakia, "Preparation and characterization of whitlockite-merwinite nanocomposite", Journal of Ceramic Processing Research, Vol. [14], No. 1, 96 99 (2013).

31.F. Tamimi, Z. Sheikh, dan J. Barralet, "Dicalcium phosphate cements: Brushite and monetite", Acta Biomaterialia, Vol. [8], 2, 474487, (2012).

32.R. G. Carrodeguas dan S. De Aza, " $\alpha$-Tricalcium phosphate: Synthesis, properties and biomedical applications", Acta Biomaterialia, Vol. [7], 10, 35363546, (2011).

33.C. Moseke dan U. Gbureck, "Tetracalcium phosphate: Synthesis, properties and biomedical applications", Acta Biomaterialia, Vol. [6], 10, 38153823, (2010).

34.J. Liao, X. Duan, Y. Li, C. Zheng, Z. Yang, A. Zhou, dan D.Zou, "Synthesis and Mechanism of Tetracalcium Phosphate from Nanocrystalline Precursor", Journal of Nanomaterials,

(2014) http://dx.doi.org/10.1155/2014/840 102.

35. A. Paz, D. Guadarrama, M. López, J.E. González, N. Brizuela, dan J. Aragón, "A comparative study of hydroxyapatite nanoparticles synthesized by different routes", Quim. Nova, Vol. [35], 9, 17241727, (2012).

36. Y. Azis, N. Jamarun, S. Arief, dan H. Nur, "Facile synthesis of hydroxyapatite particles from cockle shells (Anadaragranosa) by hydrothermal method", Oriental Journal of Chemistry, Vol. [31], 2, 1099-1105, (2015).

37.D. Zhou, C. Qi, Y-X. Chen, Y-J. Zhu, T-W. Sun, F. Chen, and C-Q. Zhang, "Comparative study of porous hydroxyapatite/chitosan and whitlockite/chitosan scaffolds for bone regeneration in calvarial defects", International Journal of Nanomedicine, Vol. [12], 26732687, (2017).

38. M. E. Fleeta dan X. Liua, "Local structure of channel ions in carbonate apatite", Biomaterials, Vol. [26], 7548-7554, (2005).

39. J. da Silva Rabelo Neto, T. B. Knopf, M. C. Fredel, S. Olate, dan P. H. de Moraes, "Synthesis and Characterization of Calcium 
Phosphate Compounds with Strontium and Magnesium Ionic Substitutions", Int. J. Morphol., Vol. [33], 3, 1189-1193, (2015).

40. Y. Y. Margaretha, H. S. Prastyo, A. Ayucitra, dan S. Ismadji, "Calcium oxide from Pomacea sp. shell as a catalyst for biodiesel production", International Journal of Energy and Environmental Engineering, Vol. [3], 33, 1-9,( 2012).

41.M. Galván-Ruiz, J. Hernández, L. Baños, J. Noriega-Montes, dan M. E. Rodríguez-García, "Characterization of Calcium
Carbonate, Calcium Oxide, and Calcium Hydroxide as Starting Point to the Improvement of Lime for Their Use in Construction", J. Mater. Civ. Eng., Vol. [21], 694698, (2009).

42. A. Lesbani, S. O. C. Sitompul, R. Mohadi, dan Nurlisa Hidayati, "Characterization and Utilization of Calcium Oxide $(\mathrm{CaO})$ Thermally Decomposed from Fish Bones as a Catalyst in the Production of Biodiesel from Waste Cooking Oil", Makara J. Technol., Vol. [20], 3, 121-126, (2016) 